\title{
PENERAPAN SIX SIGMA DALAM UPAYA MENURUNKAN JUMLAH PRODUK CACAT PADA PROSES PERCETAKAN SURAT KABAR PADANG EKSPRES
}

\author{
NOVA MELISTY, MAIYASTRI, HAZMIRA YOZZA \\ Program Studi Matematika, \\ Fakultas Matematika dan Ilmu Pengetahuan Alam, Universitas Andalas, \\ Kampus UNAND Limau Manis Padang, Indonesia. \\ email : melistynova@yahoo.com
}

\begin{abstract}
Abstrak. Salah satu program peningkatan kualitas yang dapat mengakomodasi tuntutan peningkatan kualitas adalah program Six Sigma dengan menggunakan metode DMAIC. Penelitian dilakukan pada PT. Padang Graindo Mediatama, salah satu perusahaan yang memproduksi surat kabar Padang Ekspres. Program digunakan untuk menurunkan persentase cacat produk. DPMO dari cacat koran dalam penelitian diperoleh nilai DPMO rata-rata sebesar 12.420 dengan nilai Sigma Level sebesar 3,76. Dari diagram pareto didapatkan tingkat kecacatan koran yang memberi kontribusi paling besar pada halaman menghitam. Dari diagram sebab akibat penyebab cacat terdiri dari faktor manusia, mesin, material dan metode.
\end{abstract}

Kata Kunci: Six Sigma, DMAIC, DPMO, dan Sigma Level

\section{Pendahuluan}

Pada era globalisasi seperti sekarang ini, tingkat persaingan antar perusahaan dalam menghasilkan suatu produk semakin meningkat. Dalam segala aktifitas, perusahaan dituntut untuk semakin efisien dalam melakukan usaha untuk meningkatkan kualitas suatu produk yang dihasilkan agar sesuai dengan tuntutan kebutuhan pasar. Untuk menghasilkan suatu produk yang berkualitas, sebuah perusahaan harus fokus pada proses produksi. Proses produksi pada perusahaan merupakan suatu proses yang menyangkut pada biaya yang dikeluarkan oleh perusahaan untuk melakukan proses manufaktur. Biaya yang dikeluarkan oleh perusahaan pada proses produksi akan meningkat apabila terjadi variasi/cacat pada produk yang dihasilkan, oleh karena itu biaya pada proses produksi sedapat mungkin ditekan dengan mengurangi terjadinya variasi/cacat pada produk agar tidak mengakibatkan kerugian yang berdampak buruk terhadap perusahaan.Untuk mengurangi jumlah produk bervariasi/cacat yang dihasilkan oleh sebuah perusahaan dapat dilakukan dengan menerapkan metode Six Sigma.

Perusahaan yang sering kali mengalami variasi/cacat pada hasil produksinya adalah perusahaan yang bergerak pada bidang percetakan, hal itu terjadi karena proses produksi dilakukan secara terus menerus untuk mengimbangi kebutuhan pasar, seperti yang terjadi pada perusahaan percetakan PT. Padang Graindo Medi- 
atama. Perusahaan ini merupakan sebuah usaha yang bergerak dibidang percetakan surat kabar harian, yaitu surat kabar Padang Ekspres. Dari proses produksinya, PT. Padang Graindo Mediatama mampu menghasilkan sebanyak 551.250 eksamplar Surat kabar Padang Ekspres dari tanggal 13 Maret 2015 sampai 13 April 2015. Dari hasil yang diperoleh, setiap harinya surat kabar Padang Ekspres mengalami kecacatan dalam proses produksi. Berbagai jenis kecacatan yang terjadi adalah gambar blur, tepi tidak rata, dan halaman menghitam. Oleh sebab itu, PT. Padang Graindo Mediatama perlu melakukan pengontrolan pada proses produksinnya dengan menerapkan metode Six Sigma, agar jumlah produk cacat yang dihasilkan tidak terlalu banyak dan tidak menimbulkan kerugian pada pihak perusahaan.

\section{Metode Six Sigma}

Six Sigma didefinisikan sebagai metode peningkatan proses bisnis yang bertujuan untuk menemukan dan mengurangi faktor- faktor penyebab kecacatan dan kesalahan, mengurangi waktu siklus dan biaya operasi, meningkatkan produktivitas dan memenuhi kebutuhan pelanggan dengan lebih baik [1].

Fase-fase dalam DMAIC yang meliputi hal-hal sebagai berikut:

(1) Tahap Define.

Langkah operasional pertama pada siklus DMAIC ini mencakup:

a. Pemilihan masalah yang akan ditanggulangi, lalu mendefinisikan masalah tersebut dengan jelas.

b. Setelah masalah tersebut didefinisikan, kemudian perlu ditetapkan tujuan yang ingin dicapai diakhir program peningkatan kualitas Six Sigma. Tujuan yang diharapkan harus jelas.

(2) Tahap Measure.

Pada tahap ini, akan dilakukan pengukuran-pengukuran pada proses atau kinerja produksi yang berlangsung.

(3) Tahap Analyze.

Pada tahap ini, akan dilakukan eksplorasi untuk membuat pemecahan dari setiap permasalahan.

(4) Tahap Improve.

Pada tahap improve ini, solusi yang telah didapat kemudian dilakukan eksperimen untuk melihat apakah solusi ini dapat menurunkan jumlah cacat atau tidak. Akan tetapi, perlu adanya prioritas dari perusahaan tentang jenis cacat yang akan diperbaiki lebih dulu untuk menekan dana yang dikeluarkan perusahaan. Perusahaan harus selektif memilih permasalahan untuk diperbaiki.

(5) Tahap Control.

Pada tahap operasional siklus DMAIC ini, berfokus tentang bagaimana upaya menjaga perbaikan agar terus berlangsung. Perbaikan ini biasa saja termasuk menentukan standar serta prosedur baru, mengadakan pelatihan bagi karyawan dan lain-lain. 


\section{Metode Penelitian}

Jenis data yang digunakan adalah data sekunder yang diperoleh dari PT. Padang Graindo Mediatama. Data yang digunakan dalam penelitian ini adalah data jumlah produk cacat pada percetakan surat kabar Padang Ekspres ada 32 observasi mulai tanggal 13 Maret 2015 sampai 13 April 2015 yang menghasilkan jumlah cacat sebesar 20.705 eksemplar.

\section{Analisis dan Pembahasan}

\subsection{Tahap-tahap DMAIC}

Adapun tahap-tahap dari proses DMAIC yang dilakukan adalah sebagai berikut:

(1) Tahap Define.

Dalam memproduksi surat kabar Padang Ekspres, PT. Padang Graindo Mediatama banyak mengalami kesalahan yang menyebabkan hasil akhir dari produk yang dihasilkan mengalami ketidaksempurnaan atau mengalami cacat produk. Produk cacat akan mempengaruhi jumlah produksi dan kerugian yang dialami pihak perusahaan, sehingga perlu dilakukan perbaikan untuk mengurangi jumlah cacat. Jenis cacat yang terjadi pada produksi surat kabar Padang Ekspres antara lain: gambar blur, tepi tidak rata, dan halaman menghitam.

(2) Tahap Measure.

Pada tahap ini akan ditentukan karakteristik CTQ serta pengukuran baseline kinerja.

a. Menentukan karakteristik CTQ (Critical to Quality)

Penetapan karakteristik kualitas CTQ yang berkaitan langsung dengan kebutuhan spesifik dari pelanggan akan sangat bergantung pada situasi dan kondisi dari setiap perusahaan.

Didalam program peningkatan kualitas Six Sigma, jenis-jenis cacat produk tersebut dapat dinyatakan sebagai banyaknya karakteristik kualitas CTQ potensial penyebab kegagalan dalam proses pembuatan surat kabar Padang Ekspres. Jadi jumlah karakteristik CTQ potensial sebanyak 3.

b. Pengukuran baseline kinerja.

Pengukuran baseline kinerja dimaksudkan untuk mengetahui sejauh mana suatu produk dapat memenuhi spesifik. Dalam pengukuran baseline kinerja digunakan satuan pengukuran DPMO dan nilai Sigma Level. Perhitungan DPMO dan Sigma Level untuk inspeksi yang dilakukan dari tanggal 13 Maret 2015 sampai tanggal 13 April 2015 dapat dilihat pada Tabel 1.

(3) Tahap Analyze.

Pada tahap ini akan dilakukan analisa data guna menetapkan target kinerja dan menentukan penyebab potensial yang mempengaruhi terjadinya produk cacat.

- Analisis Pada Pengolahan Koran

Dalam pengolahan surat kabar Padang Ekspres terdapat beberapa tahapan yaitu materi/isi halaman yang sudah selesai di layout oleh tim cetak 
Tabel 1. Kapabilitas Sigma dan DPMO

\begin{tabular}{|c|c|c|c|c|c|c|c|c|}
\hline Observasi & $\begin{array}{c}\text { Banyak produk } \\
\text { yangdiperiksa }\end{array}$ & Gambar blur & \begin{tabular}{|c|} 
Tepi tidak \\
rata
\end{tabular} & $\begin{array}{c}\text { Ealaman } \\
\text { menghitam }\end{array}$ & total cacat & DPO & DPMO & Sigma \\
\hline 1 & 16300 & 412 & 153 & 260 & 825 & 0,016871 & 16.871 & 3,623 \\
\hline 2 & 17.150 & 244 & 206 & 443 & 893 & 0,017357 & 17357 & 3,612 \\
\hline 3 & 15500 & 241 & 161 & 295 & 697 & 0,014989 & 14989 & 3,670 \\
\hline 4 & 18.600 & 255 & 101 & 168 & 524 & 0,009391 & 9391 & 3,850 \\
\hline 5 & 17.650 & 168 & 130 & 145 & 443 & 0,008366 & 8366 & 3,893 \\
\hline 6 & 18500 & 145 & 328 & 550 & 1023 & 0,018432 & 18.432 & 3,587 \\
\hline 7 & 17.600 & 302 & 181 & 752 & 1235 & 0,02339 & 23390 & 3,488 \\
\hline 8 & 17500 & 137 & 168 & 115 & 420 & 0,008 & 8.000 & 3,909 \\
\hline 9 & 10300 & 63 & 107 & 45 & 215 & 0,006958 & 6958 & 3,959 \\
\hline 10 & 15.600 & 80 & 98 & 196 & 374 & 0,007991 & 7991 & 3,909 \\
\hline 11 & 18.800 & 215 & 121 & 181 & 517 & 0,009167 & 9.167 & 3,859 \\
\hline 12 & 17550 & 130 & 61 & 595 & 786 & 0,014929 & 14929 & 3,672 \\
\hline 13 & 19.600 & 366 & 160 & 92 & 618 & 0,01051 & 10510 & 3,808 \\
\hline 14 & 18.750 & 181 & 289 & 94 & 564 & 0,010027 & 10.027 & 3,825 \\
\hline 15 & 17.600 & 244 & 191 & 626 & 1061 & 0,020095 & 20.095 & 3,552 \\
\hline 16 & 17200 & 313 & 115 & 290 & 718 & 0,013915 & 13915 & 3,700 \\
\hline 17 & 15500 & 241 & 179 & 438 & 858 & 0,018452 & 18.452 & 3,587 \\
\hline 18 & 19300 & 121 & 215 & 181 & 517 & 0,008929 & 8929 & 3,869 \\
\hline 19 & 18900 & 282 & 160 & 221 & 663 & 0,011693 & 11.693 & 3,767 \\
\hline 20 & 19.800 & 160 & 153 & 305 & 618 & 0,010404 & 10.404 & 3,811 \\
\hline 21 & 18.200 & 282 & 275 & 128 & 685 & 0,012546 & 12546 & 3,740 \\
\hline 22 & 10.600 & 89 & 63 & 54 & 206 & 0,006478 & 6.478 & 3,985 \\
\hline 23 & 16.800 & 214 & 115 & 237 & 566 & 0,01123 & 11230 & 3,782 \\
\hline 24 & 15.800 & 188 & 71 & 241 & 500 & 0,010549 & 10549 & 3,806 \\
\hline 25 & 19.700 & 114 & 208 & 275 & 597 & 0,010102 & 10.102 & 3,823 \\
\hline 26 & 18550 & 244 & 321 & 244 & 809 & 0,014537 & 14537 & 3,682 \\
\hline 27 & 18.600 & 344 & 435 & 275 & 1054 & 0,018889 & 18.889 & 3,577 \\
\hline 28 & 17.600 & 154 & 322 & 201 & 677 & 0,012822 & 12.822 & 3,732 \\
\hline 29 & 16200 & 137 & 160 & 206 & 503 & 0,01035 & 10350 & 3,813 \\
\hline 30 & 17.800 & 198 & 137 & 229 & 564 & 0,010562 & 10562 & 3,806 \\
\hline 31 & 15500 & 134 & 232 & 152 & 518 & 0,01114 & 11.140 & 3,786 \\
\hline 32 & 18.200 & 208 & 101 & 148 & 457 & 0,00837 & 8370 & 3,892 \\
\hline Total & 551250 & 6606 & 5.717 & 8382 & 20.705 & 0,397439 & 397.439 & 120,3746 \\
\hline rata-rata & 172265,625 & 206,4 & 178,66 & 261,938 & 647,03 & 0,01242 & 12.420 & 3,76 \\
\hline
\end{tabular}

redaksi dipindahkan ke plat melalui proses pra cetak melalui CTP ( $\mathrm{Com}$ puter To Plat) maka mesin akan memproses data yang ada dimonitor sesuai dengan intruksi operator, kemudian mesin memproses dan mengeluarkan plat yang berisi halaman. Proses pelipatan plat sesuai dengan ukuran dan ketentuan, plat yang sudah mengalami proses dan lipatan dipasang pada unit-unit mesin (pasang plat ke selinder plat), kemudian jalankan mesin dengan pelan, jalankan semua rol tinta dan rol air, apabila plat yang diselinder sudah disiram air lakukan register gambar, dan apabila gambar sudah masuk, mesin dijalankan sekaligus rem kertas di stel sampai tepi kertas rata, warna koran juga di stel, selanjutnya koran akan 
tercetak.

- Analisis Perhitungan Nilai DPMO dan Nilai Sigma Level

Pada perhitungan yang telah dilakukan pada Tabel 1 didapat nilai ratarata DPMO sebesar 12.420 dengan rata-rata Sigma Level sebesar 3,76, hal ini menunjukkan bahwa pada proses pembuatan surat kabar Padang Ekspres di PT. Padang Graindo Mediatama memiliki tingkat kapabilitas proses diatas rata-rata industri di Indonesia tetapi di bawah industri di USA sesuai dengan Tabel 1 Nilai DPMO sebesar 12.420 dapat disimpulkan bahwa dari satu juta kesempatan akan terdapat 12.420 kemungkinan bahwa proses produksi surat kabar Padang Ekspres menghasilkan produk yang cacat.

- Analisis Penyebab Potensial Cacat

\section{a. Diagram Pareto}

Analisis selanjutnya dilakukan dengan menggunakan diagram Pareto untuk mengetahui CTQ potensial yang paling tinggi yang dapat menimbulkan kecacatan dalam proses produksi surat kabar Padang Ekspres. Dari Tabel 1 diatas, maka disusunlah diagram Pareto untuk cacat surat kabar Padang Ekspres seperti pada gambar 1 berikut

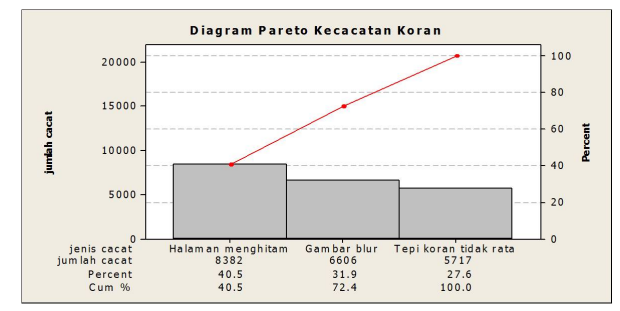

Gambar 1. Diagram Pareto kecacatan surat kabar Padang Ekspres

Pada Gambar 1 dapat dilihat bahwa di dalam proses pembuatan surat kabar Padang Ekspres, jenis cacat yang mendominasi adalah halaman menghitam dengan nilai 8.382 unit yang memberikan kontribusi sebesar 40,5. Halaman menghitam pada surat kabar Padang Ekspres merupakan penyebab kecacatan yang paling sering terjadi.

b. Diagram sebab-akibat.

Adapun penyebab dari cacat halaman menghitam adalah sebagai berikut: Faktor manusia diakibatkan oleh kelalaian dan ketelitian karyawan dalam produksi merupakan faktor yang menyebabkan kecacatan dalam produksi, misalnya pada pemasangan rol yang tidak teliti sehingga air tidak naik ke plat, karena air tidak naik ke plat, apabila mesin sudah dinyalakan maka hasilnya akan menghitam. Fonten kurang, stelan warna terlalu tebal sehingga koran menjadi hitam, dan penyetelan rol air tidak pas.Faktor mesin terjadi akibat rol air pecah sehingga baring ikut pecah mengakibatkan baring melonggar, rol kon- 
dom robek sehingga air tidak naik dan dibagian yang robek tersebut akan menghitam, rol tinta pecah, baring pecah, dan dinamo mati yang membuat air tidak jalan sehingga koran menghitam. Faktor material terjadi karena tinta yang digunakan kalau tidak sesuai dengan standar, misalnya tinta terlalu encer maka tinta akan cepat keluarnya yang mengakibatkan tulisan nya menjadi tebal dan hitam, kalau tinta terlalu keras maka akan lama turunnya sehingga tulisan menjadi kabur. Fonten yang tidak sesuai dengan standar juga akan membuat halaman menghitam karena air yang digunakan untuk mencuci plat tidak dapat bercampur dengan fonten sehingga plat tidak akan bersih dan menyebabkan halaman menghitam.Sedangkan faktor metode terjadi karena mesin yang dijalankan pada saat proses operasi seringkali dijalankan tidak sesuai dengan ketentuan yang menyebabkan proses produksi tidak konsisten.

Adapun diagram sebab akibat cacat halaman menghitam sebagai berikut

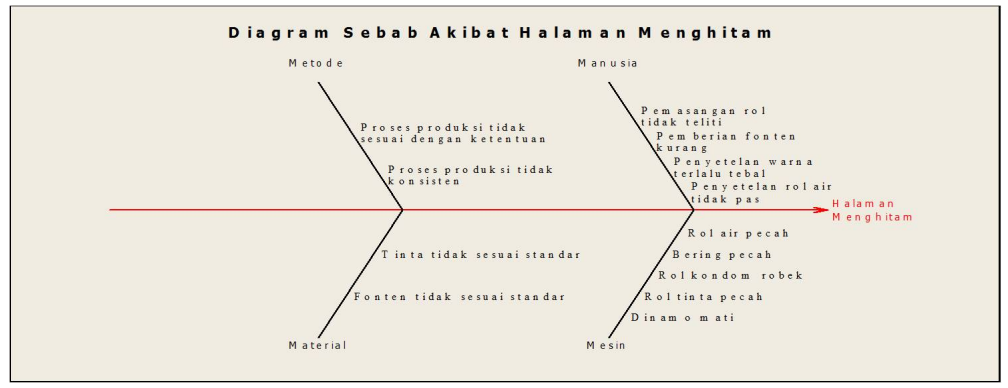

Gambar 2. Diagram sebab akibat halaman menghitam

\section{c. Peta Kendali u}

Peta kendali u merupakan peta kendali yang menunjukkan rata-rata banyaknya jenis ketidaksesuaian per unit. Gambar dibawah ini menunjukkan peta kendali untuk jumlah cacat surat kabar Padang Ekspres

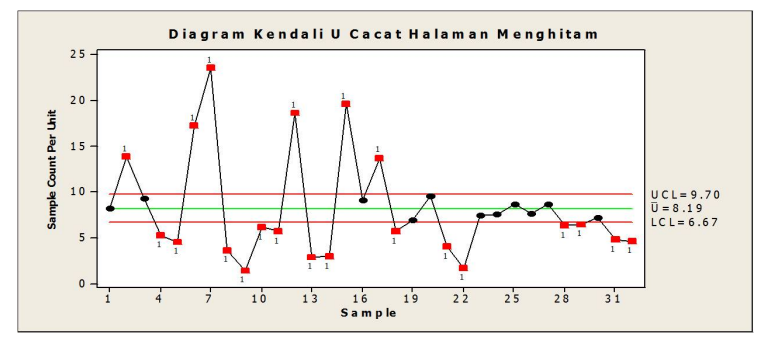

Gambar 3. Peta kenddali u cacat halaman menghitam 
Dari peta kendali u diatas terlihat bahwa pada jenis cacat halaman menghitam data tidak terkendali karena kebanyakan data berada di luar batas kendali.

\section{Tahap Improve}

Pada tahap ini yang perlu dilakukan adalah menetapkan rencana tindakan, seperti yang telah diterangkan pada tahap Analyze, bahwa karakteristik penyebab cacat pada surat kabar Padang Ekspres yaitu gambar blur, tepi tidak rata, dan halaman menghitam, sehingga perlu dilakukan tindakan untuk mengurangi tingkat kegagalan produk (defect) dan tindakan untuk mengurangi cacat halaman menghitam.

Untuk faktor manusia, perlu dilakukan perbaikan kerja dalam pengolahan surat kabar dengan cara melakukan pengontrolan oleh kepala percetakan kepada bawahannya (karyawan), memberikan nasehat-nasehat kepada karyawan agar mempunyai sikap memiliki dan menjaga, serta bertanggung jawab dalam melakukan pekerjaan. Karyawan diberikan arahan-arahan dalam menjalankan pekerjaan agar ketelitian dalam bekerja dapat ditingkatkan.

Faktor mesin, perlu dilakukan tindakan seperti komponen-komponen pada mesin yang rusak seharusnya diganti sesuai dengan periode penggantiannya agar tidak menghasilkan produk yang cacat serta diperlukan pengontrolan dan perawatan mesin yang lebih teratur.Faktor material, perlu dilakukan perbaikan agar cacat halaman menghitam tidak terjadi, caranya adalah tinta yang digunakan pada percetakan harus sesuai dengan standar, sehingga tidak ada tinta yang terlalu cair dan terlalu keras, kemudian gunakan fonten yang sesuai dengan standar supaya bisa bercampur dengan air sehingga dapat membersihkan plat, kalau plat bersih maka tidak akan terjadi halaman menghitam.

Sedangkan faktor metode, perusahaan harus menetapkan standarisasi metode yang sama yang digunakan dalam proses produksi sehingga setiap karyawan memakai metode tersebut, menetapkan ketentuan yang kuat agar tidak dilanggar oleh karyawan dan perlu adanya pengawasan yang ketat terhadap karyawan agar karyawan melakukan proses produksi sesuai dengan ketentuan, dan memberikan sanksi kepada karyawan yang bekerja tidak sesuai dengan ketentuan yang telah ditetapkan.

5. Tahap Control

Pada tahap ini dilakukan percobaan dari rencana perbaikan (improve) yang didapat pada pembahasan sebelumnya. Langkah-langkah yang terdapat pada improve yaitu, untuk mengatasi beberapa masalah cacat dapat didokumentasikan, disebarluaskan dan dibuat standar pedoman kerja. Pada tahap ini, tidak hanya didokumentasikan saja, namun harus dilakukan monitoring dan evaluasi terhadap tahap improve yang sudah ada, karena kalau tidak dilakukan, kemungkinan cara-cara lama akan muncul lagi sehingga menyebabkan kecacatan.

Tahap control, tidak dapat dilkukan oleh peneliti, karena pengontrolan ini merupakan wewenang dari pihak perusahaan dan tahap control ini dilakukan dalam waktu yang lama karena control ini harus dilakukan terus menerus, sementara peneliti memiliki waktu yang terbatas. 


\section{Kesimpulan}

Berdasarkan analisis data pada peningkatan kualitas Six Sigma yang telah dilakukan, maka dapat diambil kesimpulan sebagai berikut:

(1) Dari perhitungan DMPO dan Sigma Level didapatkan nilai rata-rata DPMO sebesar 12.420, dapat diinterpretasikan bahwa dari satu juta kesempatan akan terdapat 12.420 kemungkinan bahwa proses produksi surat kabar Padang Ekspres menghasilkan produk yang cacat, dengan rata-rata Sigma Level sebesar 3,76 , hal ini menunjukkan bahwa pada proses pembuatan surat kabar Padang Ekspres di PT. Graindo Mediatama memiliki tingkat kapabilitas proses diatas rata-rata industri di Indonesia.

(2) Berdasarkan analisis pada diagram Pareto cacat surat kabar Padang Ekspres data atribut, didapatkan bahwa dalam proses pembuatan surat kabar Padang Ekspres jenis cacat yang paling tinggi adalah halaman menghitam dengan nilai 8.382 unit yang memberikan kontribusi sebesar 40,5\%. Dari diagram sebab akibat dapat diketahui penyebab terjadinya cacat halaman menghitam pada surat kabar Padang Ekspres adalah karena pemasangan rol tidak teliti, fonten kurang, stelan warna tebal, stelan rol air tidak pas, rol air pecah, baring longgar, rol kondom robek, rol tinta pecah, dinamo mati, tinta tidak sesuai standar, dan fonten tidak sesuai dengan standar.

Cara mengatasinya yaitu: melakukan pengontrolan oleh kepala percetakan kepada bawahannya (karyawan), memberikan nasehat-nasehat kepada karyawan agar mempunyai sikap memiliki dan menjaga, serta bertanggung jawab dalam melakukan pekerjaan, diberikan arahan-arahan dalam menjalankan pekerjaan agar ketelitian dalam bekerja dapat ditingkatkan, memberikan sangsi tegas kepada karyawan yang melanggar peraturan, komponenkomponen pada mesin yang rusak seharusnya diganti sesuai dengan periode penggantiannya, tinta yang digunakan pada percetakan harus sesuai dengan standar, sehingga tidak ada tinta yang terlalu cair dan terlalu keras, kemudian gunakan fonten yang sesuai dengan standar supaya bisa bercampur dengan air sehingga dapat membersihkan plat, kalau plat bersih maka tidak akan terjadi halaman menghitam, harus ada standarisasi metode yang digunakan dalam proses produksi.

Dari peta kendali u terlihat bahwa dari setiap jenis cacat, data yang dihasilkan tidak terkendali karena berada diluar batas kendali, ini disebabkan karena faktor-faktor penyebab diatas sehingga perlu dilakukan perbaikan terhadap produksi koran Padang Ekspres.

\section{Daftar Pustaka}

[1] Montgomery, D.C. 2001. Introduction to Statistical Process Control, Sixth Edition. International Student Version. Arizona

[2] Hidayat, A. 2007. Peta pengembangan Kualitas dan Kinerja Bisnis. Jakarta

[3] Grant, E.L dan R.S. Leavenworth. 1996. Pengendalian Mutu Statistik Jilid 1 Edisi keenam. Erlangga, Jakarta 